\title{
Research Methodology in the Domain of Islamic Studies
}

\author{
Shahzadi Pakeeza * \\ Humaira Jahangir***
}

\begin{abstract}
The most important thing given by Allah Almighty to the human being is thinking power. It enables them different from other creatures of the world. Humans thinking act, built and rebuilt his life. Allah Almighty, therefore, ordered man to think, investigate and research. This study is based on the overview of research methodology in the field of Islamic Studies. Since the domain of Islamic studies is mainly based on the Holy Quran and Ahadith or Sunnah. This paper presents a close revision for conducting a research with special reference to data handling and analysis, text and speech analysis etc. in context with Islamic studies.
\end{abstract}

Keywords: research, speech, text, analysis, Quran, Islam

\section{Introduction}

Allah Almighty has revealed the Holy Quran as a manuscript of hidayah (divine guidance). In the Holy Quran, two methods are laid down for acquisition of guidance (hidayah). First, by reviewing ayah al-maqruah (the understandable signs) which is directly connected to the Holy Quran (its explanation is present in the Sunnah) - also well-known as ayah qawliah (the uttered signs). Second method is achieved by reviewing ayah al-manzurah (the apparent signs) which deals with the corporeal and social occurrences also acknowledged as ayah kawniyyah (the innate signs). The knowledge gained from the Holy Quran (as well as the Sunnah) is no doubt superior to supplementary sources of

\footnotetext{
${ }^{*}$ Dr. Shahzadi Pakeeza Assistant Professor, Department of Islamic Studies, Fatima Jinnah Women University, Rawalpindi. dr.pakeeza@fjwu.edu.pk

${ }^{* *}$ Ms. Humaira Jahangir Research Scholar, Department of Islamic Studies. Fatima Jinnah Women University, Rawalpindi.
} 
information. Unsurprisingly, as in further religious disciplines such as aqidah, fiqh, akhlaq, tafsir and hadith studies, and dawah, sciences should uphold Holy Quran and Sunnah as the ultimate sources of knowledge. ${ }^{1}$ A human has been awarded with services that are important for man to carry out the tasks given by Allah Almighty. The most important thing given by Allah Almighty is thinking power. The power of thinking makes man different from other creatures. Humans thinking act, built and rebuilt his life. Because of thinking humans came to know what is wrong and what is right. If humans think in a right way his/her life will become pleasant and thinking of right thing makes his life admirable and thinking of bad thing makes his/her life time blameworthy.

In the Holy Quran, Allah Almighty has said several times to think again and again in each and every matter whether the matter is right or wrong. These include (tafakkur, tadabbur, tafaqquh and ta'aqqul). The meaning of these words is not directly mentioned in the Holy Quran but carry same meanings related to thinking. ${ }^{2}$ The method of understanding the chapters of the Holy Quran and hard work to raise His teaching and commandment is called tadabbur. Tadabbur is a method to get the meanings of the Holy Quran deeply. The life in which a person understands the Holy Quran and thinks about it deeply is a great blessing by Allah Almighty, his/her life will become pleasant. Man who believes on words of the Holy Quran will get protection by Allah Almighty and Allah Almighty will help them in each and every field of life. ${ }^{3}$ Humans found some difficulties while studying the Holy Quran and this is a reason which keeps away the humans from tadabbur Quran. ${ }^{4}$

The term research is a derived in the sense of search by prefacing Reto Research. The expression Re- emanated from Latin through deeprooted French which measures "a novel" like the term "restructure" from "form". It is regarded as an action that comprehends and upsurges the summation of human acquaintance. It is catered as a creative effort assumed on a methodical foundation in accordance to upsurge the standard of knowledge, comprising the knowledge of humankind, culture and civilization, and the usage of this standard of information to invent new applications. The action of an investigation may be characterized as basic, strategic, applied and experimental research. 
Pure Research is predestined for theoretical determinations. Extended term assistances are not envisioned in it.

Strategic Research revenues the movement completed for the innovation of a resolution against the durable condition and practical difficulty, principally at the period when the effort is under consideration by the investigator.

Applied Research is prepared with an assessment of its presentation in a specific arena of life.

To attain these conclusions, certain limitations are fixed, in every discipline whichever of pure disciplines or social disciplines.

\section{Importance of Islamic Research}

a. To nurture the sense of wonder at the supremacy, wisdom and strength of Allah Almighty, this leads to an increment in the belief of the investigator, his humbleness and appreciation to Allah Almighty.

b. To identify his Inventor i.e. FIKR $\longrightarrow$ ZIKR

c. To give significance to the emblems read whether present in the Holy Quran or deals with the signs in the world of foundation leading to sense in life. This connotation produces valuable knowledge aimed at the advantage of mankind.

d. To bounce more conviction to information (not conjecture/shakk)

$$
\text { i.e. "ayn al-yaqin } \Longrightarrow \text { ilm al-yaqin } \Longrightarrow \text { haq al-yaqin" }
$$

Research generally indicates diligent and organized enquiry to determine or refine particulars of knowledge relating to any particular arena of endeavor. The principle of enquiry in any arena is to spread knowledge, and also tells how to manage the mandate of the subject; a valid methodology must to be established by authorities and experts of the area. A close revision of the kind of various fields propose that the presentation of unacceptable approach to study can put the particular field at hazard, and thus, resulting investigation in that circumstance will be defective, not as useful to the area of study which is under consideration. Research is aided as a building block upon which any real contribution of understanding is built, and henceforth, it is significant for specialists and professionals of any are not articulate effective methodological basis upon which study will be founded 
without cooperating the all-purpose aim and purposes of their particular domains.

The apprehension of investigators in the field of Islamic Studies relates to the precision, authenticity and consistency of explanation of the significance of Islam enclosed in the Holy Quran and Sunnah, their debate therefore on the approach of human civilization or human evolution founded on the administrative philosophies of the exposure. $^{5}$

\section{Islamic Studies as the Domain}

Scholars in the arena of Islamic Studies are actually the inheritors of the Allah Almighty's Prophets, getting the bequest of engaging entities into the course of Allah Almighty. The primary assignment of their investigation therefore ought to tackle the problems and accomplish the general theme rather than softening their range of occupation by relating to topics that could not enlighten the meaning of Islam and relating research themes. In the similar manner, the investigators as specified by the Holy Quran should inspire the pious ones, warn the transgressors or organize the useful ways aided as a significant involvement for the advantage of the inquisitive thoughts in the creation of the philosophers. This is also stated in the Holy Quran in the following words:

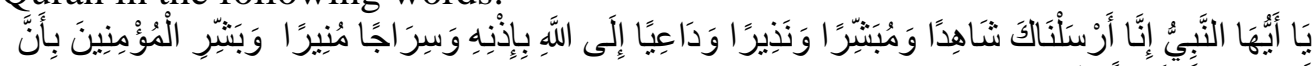

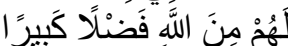

"O Prophet! Verily We have sent you as witness and a bearer of glad tidings and a Warner, and as one who invites to Allah by His leave and as a lamp spreading light (through your instructions from the Quran and Sunnah)."’6

\section{Guidelines to Islamic Studies Research Methodology}

Islamic Studies encompasses six foremost themes, including the Holy Quran Studies, Hadith Reports, Usul al-Din (principles of belief), Fiqh (Jurisprudence) Sirah (biography of the Holy Prophet Muhammad) and civilization. For the assistance of canvassers, the arena can be characterized into four subdivisions of scholarship.

- The first subdivision studies the wide-ranging laws and declarations concerning to Islamic legitimate requirements on 
subjects of Ibadah. Its major capacities of investigation are five main stays of Islam, allocating with the different concepts such as Shariah law, economic dealings and family decrees.

- The second domain concerned with Usul al-Din, which analyses matters of faith. Its major expanse of study relates to the six courses of belief, also studies al-Milal wa al-Nihal, a relative study of innumerable groups, offshoots and also different creeds which are out of the biosphere of Islam. The unseen topics such as Day of Resurrection, appearance of Isa, Mahdi, the earth beast, Gog and Mogog are also deliberate within this subdivision of scholarship.

- The third subdivision deals with the implements and revenues to the Shariah requirements, supporting or permitting better consideration of the Islamic Studies subjects. These themes are the ways through which exactness and accuracy of Shariah requirements is achieved. It studies issues such as Usul al-Fiqh (Principles of Jurisprudence), classical Arabic language, Morphology, Sirah, Science of Hadith, Sciences of the Holy Quran and Tajweed.

- The fourth branch is related with development, which discourses questions relating to Muslim dogmatic thought, finances, education and some other social characteristics of human existence.

\section{A Way to Findings in Islamic Research}

A close scholarship of such branches of research suggest the Islamic Findings to be categorized into three zones of investigation, all of them are characterized with irregular method and technique, only in particular points they inter-weave only. The first necessitates the approach of Fuqaha (Jurists), deliberating al-Ahkam al-Shari'ah (legal commandments), dealing with Ayat al-Ahkam (the Holy Quran permissible studies), al-Ahadith Ahkam (Hadith lawful Studies) and in last the assistances of the Islamic Jurists in the relevant field. Investigators in this zone appear as a renowned jurist, and investigation documents fashioned contain authorized matters and clarifications. The scholars in this space should access al-Risala of Imam al-Shafi'i, who set down the foundation and the technique to 
interpret the Holy Quran and the Prophetic traditions, understanding al-Am (General word) and al-Khas (Specific term), Mutlaq (Absolute word) and Muqayyad (conditional term), Naasikh and al-Mansookh (abrogate and abrogated ayah) and other notions of that kind. Imam al-Shafi'i highlighted that perception of the Holy Quran necessitates Arabic philological; an investigator therefore desires should prosper. Meanwhile, the scholar uses the supervision of the Holy Quran and the Prophetic traditions as the foundation of lawful Qiyas (analogical reasoning), and in the situation of Darurat (Obligation or Compulsion), the researcher choices to the ideologies of Maslaha (municipal interest). ${ }^{7}$

The second part of investigation is related to Usul al-Din, also called Tawhid. Investigators in this zone are transcribers of the Holy Quran and the Sunnah on issues related to the essentials of faith. They utilize the approach of learned scholars in their explanations and investigations, but they are not bound to accept the philosophies of

Qiyas and Maslaha.

The third part of study within the area of Islamic Scholarships is the arena of Hadith and Evolution. This area includes various arenas of Hadith Sciences, Muslims assistances in policymaking, economics, antiquity and additional similar themes. The methodology lawful for this expanse relates to the scholars of Hadith, who are not considered as the commentators of the Holy Quran and Sunnah, but formulate the pertinent material for exegetics of heavenly revelation. They perform it by determining the legitimacy and consistency of intelligences or workings upon which lawful verdict is grounded. The procedure is also legal in determining historical evidences, establishing associations and worth of it. Ibn Khaldun in his life-threatening investigation on the faults committed by investigators in the arenas of history stated things which include incapability of the investigator to fully comprehend the rules leading the conversion of human civilization, inability to abode events in their real context.

Likewise, this capacity involves explorers, in which catering with Makhtutat (documents) workings can finest be amended, using the procedure of determining the legitimacy and consistency of scripts 
connected to its output, counterfeits and its periodicals. This part of investigation is totally about modification of culture, tradition, documents of insight or refining the excellence of manufactures in civilization reliable with the essence and purposes of Islam. It also includes the responsibility of the investigators in this part as previously stated is formulating the relevant material, and including the philosophies of allocating with problems of evolution is identical with the procedure of Hadith Researchers in defining the consistency of description. The resource persons are consulted in the particular field relating to work on civilization. In such condition, their responsibility falls externally the area of the Islamic Analyses as directly no linkage is connected to the Shariah, neither they are preparing the facts, somewhat they are creating contribution to humankind as kinsmen of techniques or occupation not transcribers of the implication of Islam. ${ }^{8}$

\section{Research Methodology Strategy from Islamic Perspective}

The research approach with reference to Islam can be categorized into the following important points:

- The Tawhidic Model, as demonstrated in the Holy Quran and the Prophetic traditions, serves as real research pattern and the Islamic Commandment as the investigation context or inquiry philosophy.

- The methodology to philosophy development, i.e., rationality and cognitive stay acquiescent to the Tawhidic pattern and is controlled by Islamic Decree concluded Islamic Jurisprudence.

- Then succeeding stratums of the study should activate in accordance to the stratums above them.

In detail, beside these most vital layers, i.e., inquiry pertaining to philosophy and methodology to theory expansion, the other subsequent stratums are qualified or composed by these primary dual layers. Therefore, the principal and the chief prerequisite being the accessibility of an investigation paradigm; an expanded view or a attitude (or viewpoints) and a traditional of methodologies is rewarded by the Tawhidic archetype or Islamic Decree and Islamic reasoning to shape a new practice. ${ }^{9}$ 


\section{Methodology for Research}

In short-term; the term search means discovery of an anticipated goal or purpose. Unique one is in pursuit of gold, profession and other preferences of life whereas the other relates to the search of Supernatural being and His qualities just like Abraham who completed a successful determination and pursuit for having accurate information about the presence of Allah Almighty. His methodology of research is described as under:-

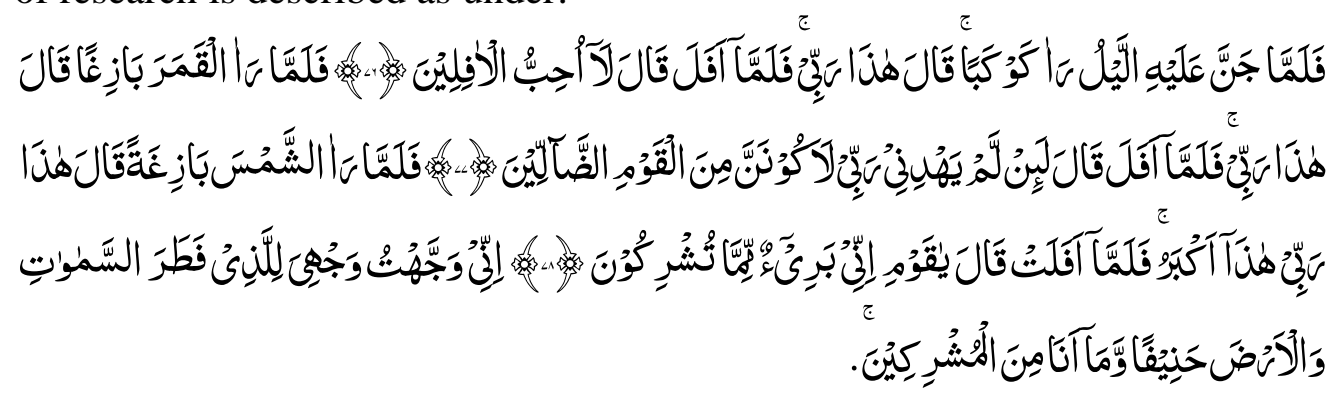

"At the time when the night prevailed upon him, he saw the star. He said, "It is my Creator." But when the star disappeared, he said, "I do not love the disappearing bodies." And when the brightening moon was seen by him, he said, "It is my Creator". And when it disappeared, he said, "Unless my Lord guides me, of course, I shall be amongst the misrouted people. And when he saw the brightening sun, he said, "It is my Creator. It is the greatest". And when it disappeared, he said, "O my fellow being, I am free from that you associate the others with Almighty God, in the matters of His Kingdom. Of course; I have put my face towards Him who has created the skies and the earth, like a man of upright nature, and; I am not amongst the idolaters." 10

From the exceeding instance, the technique and mode to be further down taken as the determination of investigation may be engaged up as:

- The basic prerequisite for undertaking an investigation is Data, besides; the term Data processes the stuff which is utilized as the substantiation either to demonstrate or to refute a fact.

- The collected Data is primary or chief which is originated from the rudimentary source and basis.

- The secondary evidences are approaching the foundations other than the origin. However; the subordinate source, occasionally, 
becomes the innovative basis for the successive investigation. In the case of Islamic subject, the primary basis of Data deals with the Holy Quran and the Prophetic traditions.

- The intellectual work throughout the third generation is to be measured as a principal foundation for the assistance of new investigator. This type of Data is both verbal and present in the printed form.

\section{Research Procedure in Islamic Studies}

The facts and figures for the determination of investigation are composed from explanations, physiological purposes, Interview, Surveys and Historical Archives.

\section{i. Observations}

Under this technique, the explanations are completed and composed for the determination of accomplishment of a just assumption against the material under disagreement. The interpretations, in certain scenarios, provide more precise evidence. The technique for making annotations is the identical way as for additional categories of descriptive investigation.

\section{ii. Physiological functions}

Data is composed as per functional purposes of the subject under revision so that disparities can be measured. As for instance, while reviewing the arena of Crime or Corruption, the subject problem under investigation will be about the wrongdoing of any individual and discuss whether that particular person is an innate immoral or there is other possibility exists. The statistics to be composed with detail including physical composition of the physique to regulate whether, the modification in these structures have any consequence which is suitable for him to become a born criminal.

\section{iii. Interview}

The third technique for building a gathering of documents is dialogue of the involved person. A precise set of inquiries are built for this determination. These may include the collected facts and figures through arena of pertinent area notes or in the form of recorded taped. 
The spirit behind the consultation is to deliver a complement to the nonfiction work and index documents.

\section{iv. Questionnaires}

These are prescribed to demonstrate a contract or discrepancy with a declaration. A survey is present both in closed and opened-end questions. The first type of questionnaire is organized for necessitating the recipient to response in Yes and No. While, under, the second type, i.e. opened-end survey, one is mandatory to give a response in some particulars.

\section{v. Historical Records}

Ancient or pre-existing evidence is also considered as a basis for Data Assortment.

\section{Method of Data Analysis in Islamic Research Methodology}

Data means confirmation, the chief entity of which relates to either evidence or to invalidate a circumstance or a point under disagreement.

- Analysis of the Subject Matter under Study

In command to be further specific and restricted for the determination a research effort, a collection is prepared of the Kind and Theme, casing the arena surrounded by which the investigator is to voyage and too endured within that domain. A further division is prepared reliant on the possibility of work.

\section{- Typology}

Typological analysis includes the classification scheme, taken from configurations, refrains, or taken from the collections for data resolutions. A separate, fashionable and exhaustive classification is completed for the determination of investigation. For further elaboration, it is also well-defined as the methodical arrangement of the categories of the somewhat rendering to their mutual features including the categories of a temperament in the study of Psychology. 


\section{- Taxonomy}

Taxonomy originated from the Greek word taxis, meaning preparation or dissection and nomos law, whereas sub ordinate classification is prepared for the determination of analysis.

It is considered as the discipline of organization rendering to predetermined arrangement, with the subsequent catalog castoff to deliver a conceptual background for conversation, analysis, or evidence retrieval. For instance, coach is a type of automobile. So any coach or car is too an automobile, but not each vehicle is considered as a car. S2o, a mechanism needs to content more constrictions to be as a car or as a vehicle. In the realm of Crime, further sub-division relating to the Corruption is prepared into three further categories, further down Islamic Law, such as Qisas, Hadood and Tazir.

\section{- Constant Comparison / Grounded Theory}

The encryptions are associated to treasure trove out reliabilities and differences. Precise events are characterized. The investigation prepared on the center of data assessment and not on the basis of one's own.

\section{Speech Analysis}

A dialogue is the communication of someone's inner spirits and enthusiasms. It always, engages an important character in guiding a human behavior towards a specific behavior. It is stated by Abdullah bin Umar that two persons visited the Holy Prophet Muhammad (peace be upon him).The dialogue made earlier the assembly fascinated the spectators to such larger magnitude that the Holy Prophet Muhammad (peace be upon him) said that; of course, there is a mystic in the description. It stated the implication of a dialogue and its consequence on human observance that Moses put an appeal before the Allah Almighty for an improved supplement in dialogue, in the practice of his brother Aaron, at the time of his visit to Pharaoh. After acceding to the request; the Almighty Allah directed Moses to low in voice while addressing Pharaoh so that the latter might had some influence. The discourse of any individual is reserved for investigating the documents. It involves revision of literature, records or folklore. 


\section{Narrative Analysis}

Statement revenue the description of certain facts either occurred or not happened at the pertinent time and the equivalent material to be investigated with allusion to that background.

Narrative investigation is a procedure of dissertation analysis that pursues to analyses the textual approaches at effort in the structures of development or categorization within a manuscript. The words utilized either in dialogue or in script are anticipated as the methodological shade by perceptive it from verbatim configuration having concern to the procedure as well as accustomed applications whether taken by the presenter or the author. For creating an investigation of the declaration or insides of a manuscript, one may drop its thinking in the subsequent situation:-

i. The ordinary and evident connotations being accessible are conveyed any of the student or the auditor. In this type, no doubt remains in accordance to the message being conveyed.

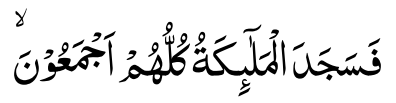

The instance thereof may be the occasion where in the angels prostrated themselves, all together. ${ }^{11}$

The word, "all of them together" show that no one was left behind for the purpose of prostration. There is no ambiguity in the text in case of clear statement; there is no need for making an analysis thereof for the purpose of further interpretation and research.

ii. Whether the declaration, either verbal or written, necessitates some additional explanation or description, for the resolution of investigation and interpretation.

This situation seems where the humble and basic connotation of the description/declaration is inadequate for the determination of and understanding or examination. A feature is lacking within. The illustration thereof is considered as the appreciation for submission of a prayer. But the method of supplication is not declared. This declaration is further enlightened by another manuscript or speech, 
"Prayer as you see me praying". This situation is called as an enabling statement.

iii. Whether the testimonial either verbal are transcribed is made focus to any situation or not?

If the declaration is made below some circumstances or exposed to certain exemptions, it is occupied as transformed situation. For the determination of language; this kind of speech is named as a proclamation supplemented by concessions. The instance thereof is as under:

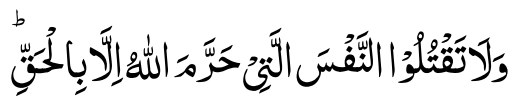

"Take not life, which Allah hath made sacred, except by way of Justice and Law."12

In this case, homicide is prohibited but may be taken away in the situation where the killing is allowed by law. The requirement of statement is changed and as a result thereof, killing of a murderer is allowed.

iv. Whether the testimonial is made focus on the selfactualization of a circumstance it verves with the presence or nonexistence of that particular condition. The example thereof may be taken of as under:

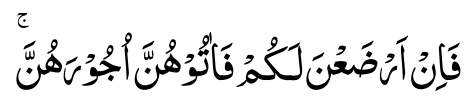

"Of course; you are duty bound, to give the labor charges to the females, in the case, they feed milk to the infant for you". ${ }^{13}$

The first prerequisite is that unique is not underneath any requirement to made payment of the wages after the termination of a marriage. However this situation is altogether change, in case of suckling of the child. In case of suckling, one is duty bound to make payment of the wages. This first situation is overtaken by the second situation. This type of statement is called as substituted or altered statement.

v. Whether it shows condition where the innovative connotations are not adequate to survive with the requisite and situations? 
In the situation, where the implications originally allocated to a manuscript are prolonged to some additional condition under an essential suggestion, this is termed as a declaration by necessity. For instance,

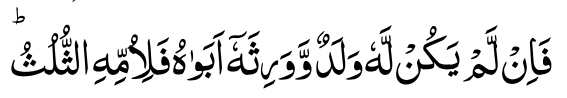

"And, in the case, the deceased is succeeded by his parents, then $1 / 3$ share is for the mother". ${ }^{14}$

The share allotted to the mother is one out of three. The father is not mentioned in this case. But by necessary implications, it is taken that the father gets the rest of the share i.e. 2/3 share out of the estate left by deceased issueless son or daughter.

\section{Discourse Analysis}

Several people conversation and not including the distinct person are engaged up for the determination of scrutiny. Semiotics, reconstruction and narrative investigation are procedures of discourse examination. A study of the way versions or the world, society, events and psyche are produced in the use of language and discourse. On the subject, there are many instances in Islamic literature and some of these are taken up as under:

i. For the purpose of a selection for the first caliph, people gathered in the compound of Salad, amongst the Ansar. After a thorough discussion, the matter was concluded in the selection of Abu Bakr.

ii. After a due consultation and discussion; the place for battle against the non-believers was opted in Badr.

iii. The prisoners of Badr were released against some considerations. It was done after a discussion despite the fact that difference of opinion was there.

iv. The dispatch of armies was done after a proper discussion and consultations amongst the member of the assembly at certain occasions.

\section{Literal Analysis}

A literal examination of a manuscript may be completed by perceiving the subsequent connotations. 


\section{- Content Analysis}

The text, manuscript or communication is understood to catch the connotation and end consequence which caters logical look. For example; what do most of the people talk about it under the custom, practice as well as under the linguistic meanings and discipline? The word Jariah stands for a maidservant as well as a boat. Therefore; it is to be taken under the situation which prevailed at the time of addressee and the speaker.

- When a manuscript is not noticeable in its basic implications, the similar is investigated by taking an orientation to the subsequent rules of explanation.

\section{Plain meaning of the Text (Ibarat al-nass)}

The examples are:

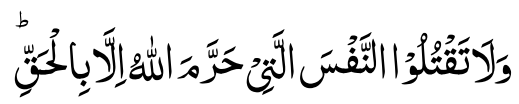

i. And you are not to kill the living person who is protected by Allah Almighty except under the right. ${ }^{15} \mathrm{~A}$ plain reading shows that homicide is prohibited. Sometimes a text may have more than one meaning; one meaning will be primary and the other will be secondary. In the verse of the Holy Quran:

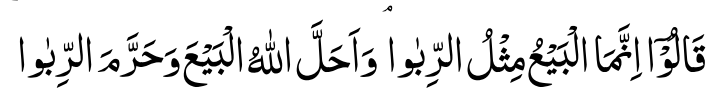

"They said, 'Of course, the sale equivalent to usury' whereas; the transaction under a sale is permitted by Allah and the usury stand prohibited." ${ }^{\prime 16}$

ii. A plain reading indicates two meanings. The first is the negation of a similarity between bay and Riba, while the second is the permissibility of Bay and prohibition of Riba. The first is the primary meaning and the second is secondary.

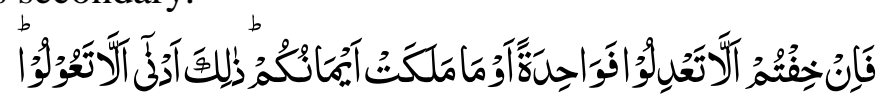

"Marry women of your choice, two, or three, or four; but if ye fear that ye shall not be able to deal justly (with them), then only one."17 
There are three meanings. The first is permissibility of marriage. The second is the restriction of marrying more than four wives. The third is the restriction of marrying only one when there is fear of causing injustice.

\section{Connotation Meanings of the Text (Isharat al-nass)}

A suggestion is obtainable in the manuscript whereby an emphasis is completed on the foremost object of transcript which, afterwards a little image, is evident within. This formation does not necessitate an orientation to some additional text. It is inside the same transcript.

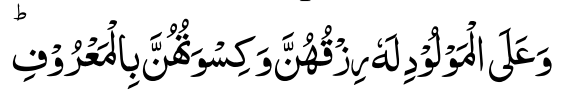

"The feeding and clothing of females is on the person whose child they are bearing". 18

A plain reading indicates that the maintenance of a wife weaning a child is on the husband. This text is also indicative of the fact that that the child is for the father.

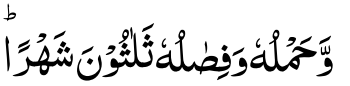

"And the period of pregnancy coupled with his weaning is thirty months." 19

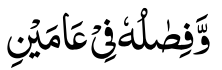

"And his weaning is within 2 years." 20

These verses, taken as a whole, are indicative of the fact that the minimum period of gestation is six months.

\section{Textual Implied Meanings (Dalalat al-nass)}

It is basically an addition of the recognized stuff, on the foundation of a collective meaning, to the other thing which is not mentioned in the text. For example,

"And never say a word of disrespect to the both.",21

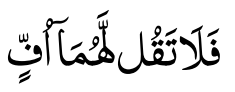
The plain reading of the text indicates that saying "fie" to parents is prohibited. As an implication thereof, the causing grievous harm to 
the parents is prohibited. So is the position with respect to abusing and beatings.

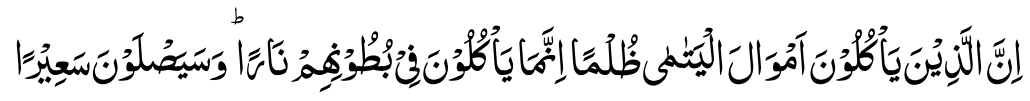

"Those who unjustly eat up the property of orphans eat up a fire into their own bodies: they will soon be enduring a blazing fire." 22

This is indicative of the fact, by plain reading, that consumption of property belonging to the orphans is prohibited. By necessary implication thereof; the setting fire to the wealth of the orphan or unjustly destroying it in any other way is also prohibited.

\section{Textual-Requirement (Iqtida al-nass)}

The word Iqtida means demand or requirement. In this context, it is a meaning required by the text in addition to what is stated by the words.

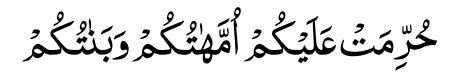

"Your mothers and your daughters are prohibited for you."23

The prohibition in this context is the prohibition for the purpose of marriage. A mention of marriage is required in the text.

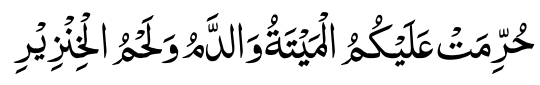

"The meat of a dead body, the blood and the flesh of swine is prohibited for you." 24

The word food or eating is not clearly mentioned here but it is the requirement of text that these are to be taken so.

\section{Opposite Meaning (Mafhum al-mukhalif)}

It is related to an indirect announcement by accepting and captivating the opposite condition with orientation to the condition explicitly cited in the manuscript. It is also called dalil al-khitab or an indirect evidence of the communication.

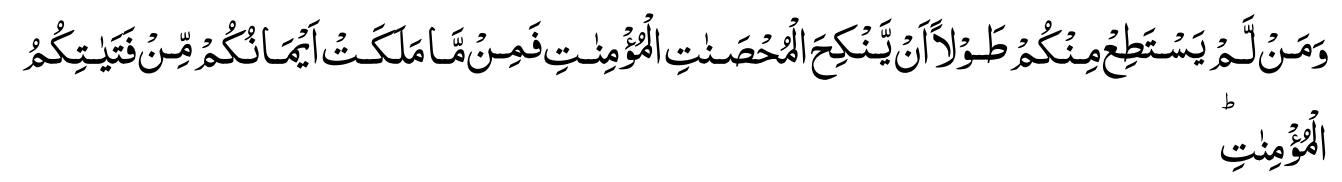


"And whosoever amongst you is unable to get marry with the free believing women, then, of course, for you are the believing girls." 25

As per the text; in the case, one is unable to marry a free woman; it is permissible for him to marry a believing slave. The opposite meaning thereof may be taken as no permission for marrying no believing slave girl. The extension of this method may be further explained and taken as under:

\section{A sense of Condition (Mafhum al-shart)}

It is a condition, where an entity is reliant on or made theme to the self-actualization or non-existence of that condition, whether to go through it, otherwise; the contrary investigation is to be performed. In the above verse, the condition for marrying believing slave girls is subject to the condition of a person's inability to marry free women. If one is able to marry a free woman, then it is not permissible for him to marry a slave girl.

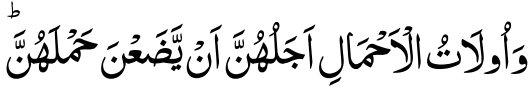

"And if they carry pregnancy, then you are to spend on them till the delivery.",26

This implies that there is no maintenance for a woman who is bearing no pregnancy.

\section{A sense of end result (Mafhum al-ghayah)}

In the case, where a limit is available in the text, after the expiry and end of that limitation, the previous state of affair is to be again operative. For example, it is permissible to eat and during Ramadan till the white of the dawn is visible. As soon this stage is over, the prohibition of eating and drinking is operative.

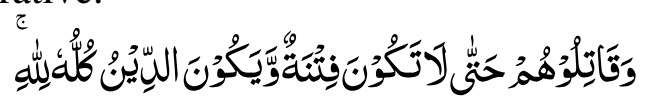

"And fight with them until there are no more disturbances and the religion as a whole becomes for Allah."27

\section{Numerical Sense (Mafhum al-adad)}

A sense other than the mentioned cannot be taken where a determined number is mentioned in the text. For instance, the hadd is prescribed 
for 100 stripes in adultery; therefore, it is to 100 stripes, neither more nor less.

\section{A sense of proper noun (Mafhum al-laqab)}

Where an intellect is connected with inappropriate noun, the wisdom for all others will be taken as an opposite. For example, where the text says, "Prohibited for you are your mothers..." it means that all persons not mentioned are permitted.

\section{Hermeneutical Analysis}

An intellect of written transcript is made. Impartial significances of the script are not observed into. The senses of the manuscript are occupied as the persons took the meanings in a condition either in prose or in philosophy. In general, this method is associated with qualitative social research.

\section{Semiotics Analysis}

The connotations of emblem and signs are controlled for the determination of creation. It is related to the analysis of sign developments (semiosis), or implication and communication, emblems and symbols, together individually and congregated into sign classifications. It comprises the revision of how sense is erected and understood.

\section{Grammatical Analysis}

\section{Syntax Analysis}

When a manuscript is not apparent in its simple meanings, the same is analyzed by having a reference to the following rules of interpretation.

\section{Common noun (Aam)}

A common noun is termed as a word which has a general application to all of the befitted person or things. The words denoting this sense are described hereinafter.

\section{i. Every}


"Every living person is to taste the death.",28

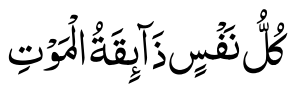

ii. Whatsoever

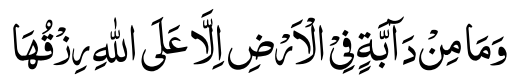

"There is no creature on the earth except whose sustenance is not made by Allah." 29

iii. All

"All that is on earth will perish." 30

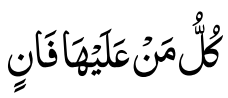

iv. All things;

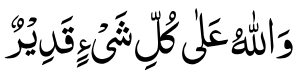

"And all thing things are within the control of Allah."31

A word may be general in the form or it may be general in its meanings.

\section{Specific word (Khas)}

When a term is functional by a solitary presentation to a restricted figure of things, counting the whole thing to which it can be applied, say one or two or a hundred and so on, it is called a specific word. A specific word is an opposite of general word. Generally; there is no Common noun but the same is made specific in its application. A word is made specific in the following manner. The words used for this purpose are:

\section{With respect to its context;}

A common noun such as a man is made specific with respect to its context. In the following verse; the man is specified as who came running from the remote place and was the informer for Moses.

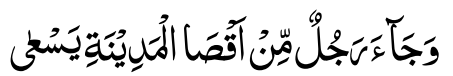

"And a man came running from a faraway area of the City." 32

i. Until 


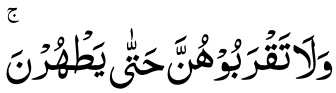

"And never come nearby the females until they are in a state of purity.",33

ii. Till

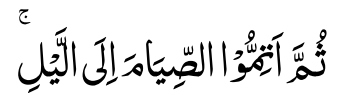

"You are to complete the fasting till the night."

iii. Except

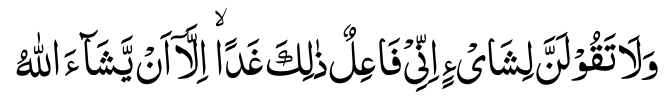

"And you are not to say about a thing, I shall do it tomorrow except under the wish of Allah." 35

iv. Who

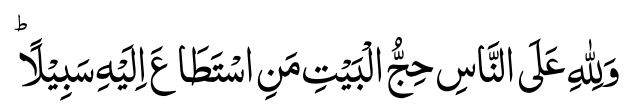

"Pilgrimage thereto is a duty men owe to God, those who can afford the journey." "36

The performance of Hajj is made particularized with the capacity of its performer.

v. Exclusion by necessary implication

"God is the Creator of all things." "37

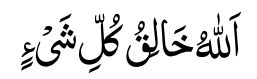

Allah is the creator of all things but not of himself.

vi. Specialized under senses

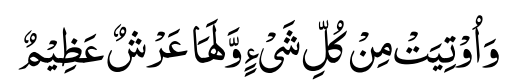

"And provided with every requisite." 38

The Queen ruling over Sabians was given everything but as a matter of fact she was not bestowed with all of the things like that of Solomon. Some things were not given to her.

vii. Made subject to condition

"Destroying all things by the commandment of its Lord." 39

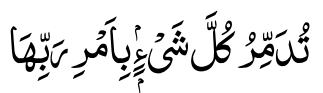

viii. Exemption 


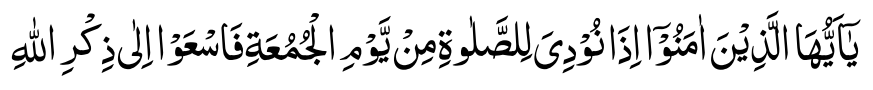

"O ye who believe! When the call is proclaimed to prayer on Friday, hasten earnestly to the Remembrance of God." 40

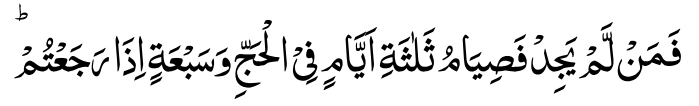

"But if he cannot afford it, He should fast three days during the hajj and seven days on his return. $" 41$

The observance of fasting during Ramdhan and during pilgrimage is made specified under certain conditions of hardship and inconvenience.

\section{Absolute (Mutlaq)}

If by a derivative or generic noun is meant the thing or a person named without any limitation, it is called absolute (Mutlaq).

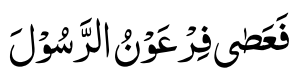

"But Pharaoh disobeyed the apostle." 42

The plain meaning of the verse is indicating that the nature and qualification of the disobedience is not limited. It is made absolute.

\section{Limited (Muqayyad)}

If by a derivative or generic noun is meant the thing named or a person with a limitation, it is called limited.

"After payment of legacies and debts." 43

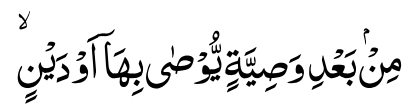

Here, the distribution of inheritance is made subject to the payment of loan or the fulfillment of a will. The absolute distribution is limited by a condition precedent thereto.

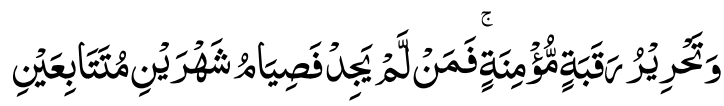

"And a believing slave is freed. For those who find this beyond their means, (is prescribed) a fast for two months running."

In this case, the neck is made specific. The same is to be a believing neck and the observance of continuous fasting is made limited and subject to the condition of non-availability of believing neck. 


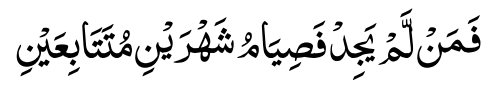

"And if any has not (the wherewithal), he should fast for two months consecutively." 45

The observance of fasting is made continuous. This condition of continuity has limited the scope of fasting.

\section{Homonyms (Mushtarak)}

A word is analyzed with respect to its applications to many things. For example, the word spring may mean a spring of water, or the spring of a clock, or the spring of a tiger.

\section{Analysis with respect to Explicit Sense}

\section{- Manifest (Zahir)}

The connotation of an expression in a path or ruling may be revealed or obscured. When it is revealed the expression is supposed to be superficial or obvious of meaning (Zahir).For instance, the meaning of the Quranic text, "God has made sale lawful and forbidden riba", is manifest so far as the legality and illegality respectively of the two transactions are concerned.

\section{- Explicit (Nass)}

If it is still further disclosed, by means of the context, it is regarded as clear or explicit (nass). In the Holy Quran

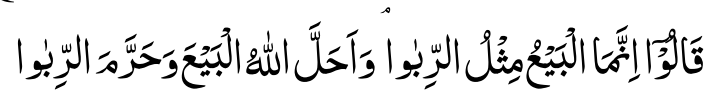

"They said, of course, the sale equivalent to usury. Whereas; the transaction under a sale is permitted by Allah and the usury stand prohibited." 46 The above Surah is regarded as explicit in distinguishing Riba from a Sale.

\section{- Elaborated (Mufassar)}

If it is so clear that no doubt remained in the field about any of the limitation in the context. It is regarded as explained or unequivocal (Mufassar). 


\section{- Unalterably fixed (Muhkam)}

And if it is made still clearer so that the possibility of repeal is precluded, it is said to be settled or unalterably fixed (muhkam).

\section{Analysis with respect to Obscurity}

\section{- Obscured (Khafi)}

The word obscured or Khafi is one whose meaning is concealed and the intention is unclear due a deficiency in the form.

- Difficult (Mushkil) or the difficult word is the opposite of Nass.

It is a word whose meaning is difficult to discover expect by evidence that removes the remaining ambiguity.

\section{- Unelaborated (Mujmal)}

It is the unelaborated word and the same is the opposite of mufassar.

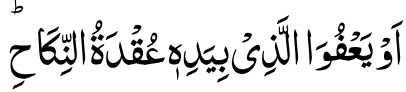

"Or it is forgiven by the man who is authorized to give her hand in marriage., 47

The relinquishment of dower is left with the domain of a person giving the hand in marriage. The husband is left at his option.

"Forbidden to you are: dead meat..."

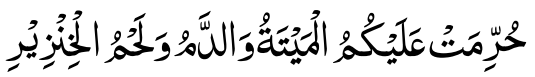

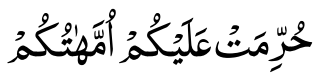

"Prohibited to you are: Your mothers." 49

The nature of prohibition, in the two verses motioned above is not elaborated.

\section{- The Unintelligible (Mutashabih)}

It is a term in which; the possibility of knowing the intention is not there.

The word thief (sariq) in Arabic language is distinct from the word nabbash and tarrar. Therefore; the applicability of punishment of cutting the hands is a matter of concern for the Judges. 


\section{Metaphorical Analysis}

In the case, a word is used in a sense other than its original meanings and application; it is called as majaz such as touching means intercourse. In this connection, various metaphors are tried such as high way in many ways such as traffic, intersections, and teachers as police officer.

\section{Method Common to Text and Speech}

\section{- Domain Analysis}

An analysis of language of people is made in a cultural context just like Punjabi, English, and Jews etc. Social situation and cultural patterns are taken up to reach a just conclusion i.e. Folk domains and mixed domains.

\section{- Analytic induction}

For the determination of Data Diagnostic, struggle is completed to inaugurate a connection between the dual prepositions in order to have a common operative reason be prolonged from the innovative basis to the novel event or fixed events. The determination is to endure till a fair conclusion is attained at. After looking solitary event another parallel event is reserved and it is then seen as that it fits as the hypothesis. For instance; the offering of prayer is forbidden for a woman during her menstruation periods. Whether this prohibition equally applies to having an intercourse during the afore-said period? It is a logical induction of the causal links between the known things and the unknown things.

\section{Logical Analysis / Matrix}

It is based on logical cognitive process. Framework of generalized interconnection is completed. In Islam, the one, while on journey, is exempted from observing Fast, in the month of Ramdhan. The reason and logic behind it is a laborious and hard walk. The problem is to be solved by making a reference to the cause of exemption in a logical manner.

\section{Quasi-Statistics}


The calculation, for the purpose of payments, under certain circumstances and certain conditions is done for smooth administration of justice.

\section{Event Analysis/Micro Analysis}

It is a frame analysis. It is a precise beginning and endings of the events within specific boundaries. The example thereof may be taken up as the assembly for the appointment of First Caliph wherein the two groups advanced their reservations and ultimately come to a definite conclusion.

\section{Tendency of Adopting a Methodology}

It recommends the following:

- Specialists in the Islamic Studies domain should join hand in hand in laying the basic principles and methodology of research in the field.

- The evaluation of any research material in the field should be measured based on its ability to be consistent with the spirit and objectives of Islamic Studies field.

- Methodology of the Jurists should be used in researches related to laws, but what relates to Tawhid or matters of comparative religion requires the methodology of Scholars of Usul al-Din.

- Areas of Hadith and civilizations requires authentication of reports and ascertaining its reliability, and thus, the methodology of Hadith Scholars is required. ${ }^{50}$

- Like other areas of knowledge and practice, the field of strategy is developing itself with newer ways to cope with the problems that arise in organization and management realm. Research methodology from Islamic perspective; provided it passes the qualifications to be a methodology, may offer its contributions to enrich this area further to overcome such problems.

- If this could lead to plausible solutions to issues, it would be accepted by the world, whatever its method of inquiry is. For the business world in general, it is not the method of inquiry that is important, it is the contribution that this methodology can make in terms of the weight of its arguments and the rigor of its analysis. 
- This needs not be confined to any one method. Rather it should remain open to all methods provided the inquiry remains within the basic framework as prescribed by Islamic Law and it is satisfying, at least, the twin criteria of reason and empirical validity.

- It should focus on analysis of the problems and their solutions instead of merely claiming that this already exists in Islam.

- This methodology has yet to be tested and verified. It may be accepted or rejected fully or partially. Moreover, its comparison with the one in Western cultural context is also a subject of a separate study.

- Another aspect which needs to be considered is the condition of presence of an Islamic state for the successful implementation of such a methodology. ${ }^{51}$

\section{Conclusion}

Specialists in the Islamic Studies domain should join hand in hand in laying the basic principles and methodology of research in the field. The evaluation of any research material in the field should be measured based on its ability to be consistent with the spirit and objectives of Islamic Studies field.

Research in Islamic studies needs not be confined to any one method. Rather it should remain open to all methods provided the inquiry remains within the basic framework as prescribed.

\section{References}

${ }^{1}$ Alizi Alias. Social Science Research Methods and Statistics from an Islamic Perspective. Malaysia: Penang. 2005.

${ }^{2}$ Badi, Jamal. "'Thinking' terminologies from Quronic perspective and their impact on human intellectual development." International Journal of Arab Culture, Management and Sustainable Development 2, no. 1 (2011), 41. doi:10.1504/ijacmsd.2011.044895.

${ }^{3}$ Salah Abd Fattah al-Khalidi. Mafatih li al-Ta'amul ma'a Al Quran. Ed.5. Damsyik: Dar al-Qalam. p.78. 2009

${ }^{4}$ Khalid bin Abd al-Karim al-Lahim. Kunci-kunci tadabbur Al Quran. Indonesia: an Naba. p. 25. 2008 
5 Yousuf Dalhat. "Introduction to Research Methodology in Islamic Studies." Journal of Islamic Studies and Culture 3, no. 2 (2015). doi:10.15640/jisc.v3n2a15.

${ }^{6}$ Al Quran. Surah Al Ihzab, verse 45-46

${ }^{7}$ Yousuf Dalhat. "Introduction to Research Methodology in Islamic Studies."

${ }^{8}$ Ibid

${ }^{9}$ Waseem Gul. "Strategy: Can a Research Methodology Be Proposed from Islamic Sources of Knowledge?" International Business Research 12, no. 7 (2019), 83. doi:10.5539/ibr.v12n7p83.

${ }^{10} \mathrm{Al}$ Quran. Surah An'am, verse 76-79

${ }^{11} \mathrm{Al}$ Quran. Surah Hijr, verse 30

${ }^{12} \mathrm{Al}$ Quran. Surah An'am, verse 151

${ }^{13}$ Al Quran. Surah Talaq, verse 6

${ }^{14}$ Al Quran. Surah Nisa, verse 11

${ }^{15}$ Al Quran. Surah An'am, verse 151

${ }^{16} \mathrm{Al}$ Quran. Surah Baqarah, verse 275

${ }^{17}$ Al Quran. Surah Nisa, verse 3

${ }^{18} \mathrm{Al}$ Quran. Surah Baqarah, verse 233

${ }^{19} \mathrm{Al}$ Quran. Surah Ahqaf, verse 15

${ }^{20} \mathrm{Al}$ Quran. Surah Luqman, verse 14

${ }^{21} \mathrm{Al}$ Quran. Surah Isra, verse 23

${ }^{22}$ Al Quran. Surah Nisa, verse 10

${ }^{23}$ Ibid. verse 23

${ }^{24} \mathrm{Al}$ Quran. Surah Maidah, verse 3

${ }^{25} \mathrm{Al}$ Quran. Surah Nisa, verse 25

${ }^{26}$ Al Quran. Surah Talaq, verse 6

${ }^{27}$ Al Quran. Surah Anfal, verse 39

${ }^{28} \mathrm{Al}$ Quran. Surah Aal e Imran, verse 185

${ }^{29} \mathrm{Al}$ Quran. Surah Hud, verse 6

${ }^{30} \mathrm{Al}$ Quran. Surah Rahman, verse 26

${ }^{31}$ Al Quran. Surah Aal e Imran, verse 189

${ }^{32} \mathrm{Al}$ Quran. Surah Qasas, verse 20

${ }^{33}$ Al Quran. Surah Baqarah, verse 222

${ }^{34}$ Ibid. verse 187

${ }^{35}$ Al Quran. Surah Kahf, verse 23-24

${ }^{36}$ Al Quran. Surah Aal e Imran, verse 97

${ }^{37}$ Al Quran. Surah Zumar, verse 62

38 A1Quan. S 23 
${ }^{39}$ Al Quran. Surah Ahqaf, verse 25

${ }^{40}$ Al Quran. Surah Jumuah, verse 9

${ }^{41}$ Al Quran. Surah Baqarah, verse 196

${ }^{42}$ Al Quran. Surah Muzammil, verse 16

${ }^{43}$ Al Quran. Surah Nisa, verse 12

${ }^{44}$ Ibid. verse 92

${ }^{45}$ Al Quran. Surah Mujadila, verse 4

${ }^{46} \mathrm{Al}$ Quran. Surah Baqarah, verse 275

${ }^{47}$ Ibid. verse 237

${ }^{48}$ Al Quran. Surah Maidah, verse 3

${ }^{49}$ Al Quran. Surah Nisa, verse 23

${ }^{50}$ Yousuf Dalhat. "Introduction to Research Methodology in Islamic Studies."

51 Waseem Gul. "Strategy:.." 